\title{
Effect of Antimicrobial Peptides on the Growth and Immunity of Swamp Eels
}

\author{
Shyh-Shyan Jan ${ }^{1}$, Dai-Qing Yang ${ }^{2}$ and Rommanee Thammasena ${ }^{1^{*}}$ \\ ${ }^{1}$ Department of Animal Science, National Chung Hsing University, Taichung 40227, Taiwan \\ ${ }^{2}$ College of Animal Sciences, Yangtze University, Hubei, 434023, China
}

*Correspondence :

aue_rommanee@hotmail.com

Received : 2020-10-16

Accepted : 2021-04-15

Keywords :

Swamp eel, Antimicrobial peptides, Blood biochemical parameters, Antioxidant, Immunity

\begin{abstract}
This study aimed to investigate the effect of different levels of antimicrobial peptides (AMPs) supplementation in the diet feed on growth performance, survival rate, biochemical parameters in swamp eels. Healthy fishes were randomly assigned to five groups feeding with different supplementation of AMPs $(0,200,400,600$, or $800 \mathrm{mg} / \mathrm{kg})$ in diets for 68 days. Results showed that relative weight gain, feed coefficient and survival rate were significantly $(\mathrm{p}<0.05)$ increased by supplementation of AMPs in feed. Level of protein (TP), triglyceride TG, alanine transaminase (ALT), alkaline phosphate (ALP), acid phosphate (ACP), superoxide dismutase (SOD), glutathione peroxidase (GPx), and catalase (CAT) in the serum were significantly $(\mathrm{p}<0.05)$ improved in all AMPs treatments, while no significant difference was found between the control and AMPs $200 \mathrm{mg} / \mathrm{kg}$. AMPs supplementation significantly enhanced $(\mathrm{p}<0.05)$ the survival rate and immune protection in swamp eels after challenged with Aeromonas hydrophila compared to the control group and eels fed with AMPs $800 \mathrm{mg} / \mathrm{kg}$ had the highest survival rate and immune protection (32.50 and $85.71 \%$, respectively). The diets containing AMPs enhanced the survival rate, immune ability, and antioxidant capacity in swamp eels, indicate that an appropriate dosage of AMPs can be used as a potential alternative to antibiotics in swamp eels.
\end{abstract}

\section{INTRODUCTION}

Antibiotics have been used as growth promoters and prevent diseases in livestock for more than 50 years. However, the misuse of antibiotics may contribute to the emergence of antibiotic-resistant bacteria and residues in meat, milk, and aquatic products (Xiao et al., 2015; Wang et al., 2016; Huang et al., 2020). The concern of antibiotic residues in meat and dairy products has become increasing due to the harmful effects on consumer health (Ramatla et al., 2017). AMPs have been noticeable as alternative antibiotic agents due to their properties included small size $(<25-30 \mathrm{kDa})$, amphipathic, cationic, and offer a low possibility for the generation microbial resistance (Cruz et al., 2014). The cationic with amphipathic properties can permit the molecule to be soluble in aqueous environments and enter lipid-rich membranes (Lei et al., 2019). AMPs possess broad-spectrum antimicrobial activity on bacteria, viruses, and fungi (Izadpanah and Gallo, 2005). They can be isolated from numerous organisms such as microorganisms, plants, and animals 
(Cruz et al., 2014). AMPs are involved in all living organism's innate immune systems and they afford the first line of defense against the invasion pathogens (Pasupuleti et al., 2011). Several AMPs have been discovered and applied in livestock, including $\mathrm{Hu}$ et al. (2017) had been studied the effect of AMPs on the growth performance and small intestinal function in broilers under chronic heat stress, Daneshmand et al. (2019) supplemented AMPs (cLF36) in broiler challenged with E. coli, and Xiao et al. (2015) studied the effect of AMPs on the growth and health promoters in swine.

Swamp eel (Monopterus albus) is a freshwater air-breathing fish that widespread from Southeast Asia to East Asia (Matsumoto et al., 2010). It is a carnivorous and nocturnal animal that prefers to consume small fish, mollusks and worms, etc. It possesses a high nutritional content with medicinal value and tasty flavor. It has become a commercially important fish that is widely farmed in some Asia countries (Khanh and Ngan, 2010) and can be cultured in tanks, aquariums, and other vessels (Miah et al., 2018). Swamp eel has a high price in China, Malaysia, Singapore, Japan, and Taiwan markets (Miah et al., 2015; Miah et al., 2018). This study aimed to investigate the effect of different levels of AMPs supplementation in the diet feed on the growth rate, serum biochemical parameters, and immune responses in swamp eels.

\section{METHODOLOGY}

\section{Place and Time}

The study is carried out at the Aquatic Animal Research Center, Yangtze University.

\section{Research Design}

Eels are assigned to five groups feeding with different supplementation of AMPs $(0,200,400,600$, or $800 \mathrm{mg} / \mathrm{kg})$ in diets for 68 days. Each treatment was made with three replications.

\section{Work Procedures}

\section{Antimicrobial Peptides (AMPs)}

Short-chain antimicrobial peptides (AMPs) from Candida utilis used in this research were kindly prepared and supported by Shenzhen Sunsmile Biotechnology Co., Ltd., (Shenzhen, China). The amino acid sequences and nucleotides of these AMPs have been not revealed due to the patent application. AMPs had a molecular mass of $\sim 1.5 \mathrm{kDa}$ and displayed broad-spectrum antibacterial activity against both grampositive and gram-negative bacteria with a minimum inhibitory concentration (MIC) range of $0.7-17 \mu \mathrm{M}$ and 3.3->150 $\mu \mathrm{M}$, respectively. Aeromonas hydrophila was kindly supported by froms Department of Aquatic Animal Medicine, Huazhong Agricultural University.

\section{Swamp Eels}

Swamp eels cultured at Aquatic Animal Research Center, Yangtze University. Before the experiment, swamp eels were acclimatized into a pond cage ( $2 \times 2 \mathrm{~m})$ and fed with the commercial diet (crude protein $54 \%$, crude fat $18 \%$, and ash $7.9 \%$ ) one per day for 14 days to adjust to the new diet and environment conditions. Thirty eels were stocked each time, new eels should be replaced when eel dead during the acclimatization period. After fasting for $24 \mathrm{~h}$, the healthy eels with uniform size at $30 \pm 5 \mathrm{~g} /$ head were selected and randomly assigned to five groups.

\section{Supplied Feed}

Feed was separately mixed with five different AMPs concentrations (0, 200, 400,600 , or $800 \mathrm{mg} / \mathrm{kg}$ ). Feed composition in each treatment is shown in Table 1. Eels have received the diet at 6.00 P.M. at the rate of $7-11 \%$ body weight for 68 days. The residue of diet and feed intake were daily recorded during the experiment. 
Table 1. The composition of basal diet.

\begin{tabular}{llllll}
\hline Item & Control & I & II & III & IV \\
\hline Fish (H) & 60 & 60 & 60 & 60 & 60 \\
Replication & 3 & 3 & 3 & 3 & 3 \\
AMPs (mg/kg) & 0 & 200 & 400 & 600 & 800 \\
Earthworm & $70 \%$ & $70 \%$ & $70 \%$ & $70 \%$ & $70 \%$ \\
Pellet feed & $30 \%$ & $30 \%$ & $30 \%$ & $30 \%$ & $30 \%$ \\
\hline
\end{tabular}

\section{Sample Collection}

On day-68, eels fasted for $24 \mathrm{~h}$, then the fishes were counted and weighted. Twelve fishes per group were randomly selected and collected the blood samples by using the tail vein blood sampling method. Blood was centrifuged at 4000 $\mathrm{r} / \mathrm{min}$ for $10 \mathrm{~min}$, then the supernatant was aspirated and stored at $-80{ }^{\circ} \mathrm{C}$ for serum biochemical analysis.

\section{Indicator determination method Growth performance}

The final body weight of each group was determined at the end of the experiment and the relative weight gain, feed coefficient and survival rate were calculated using the below formulas:

Relative weight gain $=\frac{\text { Final weight }- \text { Initial weight }}{\text { Initial weight }} \times 100$

Feed coefficient $=\frac{\text { Feed intake }}{\text { Weight gain }}$

\section{Determination of biochemical indicators and immune indicators}

Eight serum biochemical and immunological indicators, including total protein (TP), triglycerides (TG), alanine transaminase (ALT), superoxide dismutase (SOD), catalase (CAT), glutathione peroxidase (GPx), acid phosphatase (ACP), and alkaline phosphatase (ALP) was determined using a commercial kit (Nanjing Jiancheng Institute Bioengineering Institute, Jiangsu, China).
Survival rate of swamp eel after challenge with Aeromonas hydrophila

At the end of the experiment, healthy eels (20 fishes) with similar weights in each group were selected and separately allowed to acclimatize for 7 days in 60L plastic drums.

Then, each fish was injected intraperitoneally with A. hydrophila at 0.4 $\mathrm{mL} /$ fish $\left(1 \times 10^{9} \mathrm{CFU} / \mathrm{mL}\right)$. Fish swimming and mortality rate were recorded every 2 $h$, and the experiment was closely observed for one week. The survival rate and immune protection were calculated using the below formulas:

Survival rate $(\%)=\frac{\text { Final number of fish }}{\text { Initial number of fish }} \mathrm{x}$ 100

Immune protection (\%) = (AMPs group survival rate - Control group survival rate) $\mathrm{x} 100$

$$
\text { Control group survival rate }
$$

\section{Data Analysis}

Data statistical analysis in this study was analyzed using SPSS 20.0 software. The results are expressed as mean \pm SEM. The differences between treatments were examined using one-way ANOVA followed by Duncan's multiple comparisons $(\mathrm{p}<0.05)$.

\section{RESULTS AND DISCUSSION Relative Weight gain, Feed efficiency and Survival rate}

The relative weight gain, feed efficiency and survival rate of swamp eels was showed in Table 2. 
Table 2. Effect of AMPs on the growth and survival rate of swamp eels.

\begin{tabular}{cccc}
\hline AMPs & Relative weight gain rate $(\%)$ & Feed coefficient & Survival rate $(\%)$ \\
\hline 0 & $152.7^{\mathrm{a}}$ & $3.21^{\mathrm{a}}$ & $87.5^{\mathrm{a}}$ \\
200 & $166.3^{\mathrm{a}}$ & $3.11^{\mathrm{a}}$ & $90.2^{\mathrm{a}}$ \\
400 & $195.2^{\mathrm{b}}$ & $2.86^{\mathrm{b}}$ & $92.5^{\mathrm{b}}$ \\
600 & $200.7^{\mathrm{bb}}$ & $2.75^{\mathrm{b}}$ & $93.6^{\mathrm{b}}$ \\
800 & $203.1^{\mathrm{c}}$ & $2.69^{\mathrm{b}}$ & $93.8^{\mathrm{c}}$ \\
\hline
\end{tabular}

The data in the table are mean \pm standard deviation $(n=6)$, and the lowercase letters of the same column data indicate significant difference $(\mathrm{p}<0.05)$.

The relative weight gain was significantly improved in all AMPs concentrations $(\mathrm{p}<0.05)$. The relative weight gain was increased with increasing AMPs concentration in the feed. The relative weight gain was $203.1 \%$ in AMPs $800 \mathrm{mg} / \mathrm{kg}, 200.7 \%$ in AMPs $600 \mathrm{mg} / \mathrm{kg}$, $195.2 \%$ in AMPs $400 \mathrm{mg} / \mathrm{kg}, 166.3 \%$ in AMPs $200 \mathrm{mg} / \mathrm{kg}$ and $152.7 \%$ in control, separately. All AMPs treatments displayed a lower feed coefficient; the lowest feed coefficient was found in AMPs $800 \mathrm{mg} / \mathrm{kg}$ at 2.69 while the control had the highest feed coefficient (3.21). Moreover, the survival rate of all AMPs treatments was significantly higher than those of control. All the AMPs groups had a survival rate of more than $90.2 \%$ and $87.5 \%$ in control.

However, no significant difference in relative weight gain, feed coefficient, and survival rate $(\mathrm{p}>0.05)$ were observed between control and AMPs $200 \mathrm{mg} / \mathrm{kg}$. The results indicated that AMPs could enhance the relative weight gain, feed coefficient and survival rate in swamp eels. The relative weight gain and survival rate were increased with the increase of the AMPs concentration in the diet. Zhou et al. (2008) reported that AMPsapidaecin enhanced the weight, daily gain, specific growth rate, survival rate and FCR in common carp (Cyprinus carpio). Su et al. (2019) found that an adequate AMPs concentration stimulates the growth performances and decreases the FCR in Epinephelus coioides. Dong et al. (2015) described that the association between AMPs and the indigenous microbial flora probably attribute to the high growth performance in common fish.

\section{Serum Biochemical Parameters}

Supplementation with AMPs in feed significantly increased $(\mathrm{p}<0.05)$ the TP level in the serum and the TP content was increased with the increasing of AMPs concentrations. The highest TP content was found in the AMPs $600 \mathrm{mg} / \mathrm{kg}$ group. It was significantly increased by $15.99 \%$ compared with the control $(\mathrm{p}<0.05)$. Moreover, AMPs significantly $(\mathrm{p}<0.05)$ decreased the TG level in swamp eels and the TG content was the lowest in AMPs $600 \mathrm{mg} / \mathrm{kg}$, which was significantly lower than that of the control by $32.10 \%$. The serum ALT activity of each AMPs group was increased to some extent and the activity was significantly $(\mathrm{p}<0.05)$ difference when used AMPs at $800 \mathrm{mg} / \mathrm{kg}$.

In this study, AMPs displayed the benefit when used as feed additives in the swamp eels. Fish serum biochemical characteristics including protein levels, enzymes and electrolytes are related to fish metabolism, nutrition, and health. These parameters show the information of fish internal organs, nutritional status, metabolic state, etc. that are helpful to assess and manage fish health status ( $\mathrm{Su}$ et al., 2019). Serum TP index is commonly used to evaluate fish nutritional and metabolic status. This index is referred to fish dietary protein content, liver metabolism, and some lesions that cause protein loss. Moreover, a high TP level in serum could be stimulated the development of fish tissues (Yang et al., 2017). Compared with the control group, the TP level in all AMPs serums significantly increased $(\mathrm{p}<0.05)$.

These results were similar to the previous reports in tilapia Oreochromis niloticus (Chen et al., 2016). TG is a type 
of lipid in blood and the levels of TG in serum are a vital parameter that returns to the metabolism of body lipid (Dong et al.,
2015). The TG content was decreased with the concentration of AMPs increased (Table 3).

Table 3. Effect of antimicrobial peptides on serum biochemical parameters of swamp eels.

\begin{tabular}{cccc}
\hline AMPs & Total protein (TP) $(\mathrm{ug} / \mathrm{mL})$ & $\begin{array}{c}\text { Triglyceride (TG) } n \\
\text { mol/mL }\end{array}$ & $\begin{array}{c}\text { Alanine transaminase } \\
(\text { ALT) }(\mathrm{U} / \mathrm{L})\end{array}$ \\
\hline 0 & $33231.20 \pm 1326.12^{\mathrm{a}}$ & $1.62 \pm 0.36^{\mathrm{a}}$ & $26.36 \pm 1.98^{\mathrm{a}}$ \\
200 & $35441.10 \pm 1212.93^{\mathrm{b}}$ & $1.57 \pm 0.23^{\mathrm{a}}$ & $26.61 \pm 2.57^{\mathrm{a}}$ \\
400 & $36075.11 \pm 1548.33^{\mathrm{b}}$ & $1.45 \pm 0.21^{\mathrm{b}}$ & $29.01 \pm 3.09^{\mathrm{a}}$ \\
600 & $38547.75 \pm 1476.57^{\mathrm{c}}$ & $1.10 \pm 0.29^{\mathrm{c}}$ & $29.80 \pm 2.07^{\mathrm{a}}$ \\
800 & $38103.94 \pm 2223.56^{\mathrm{c}}$ & $1.21 \pm 0.29^{\mathrm{c}}$ & $31.61 \pm 5.32^{\mathrm{b}}$ \\
\hline
\end{tabular}

The data in the table is the mean \pm standard deviation $(n=6)$, the lower column of the same column data indicates that the difference is significant $(\mathrm{p}<0.05)$.

Control exhibited the highest TG content at $1.62 \mathrm{~mol} / \mathrm{mL}$. These results demonstrated that feeding eels with AMPs could decrease TG in serum and it was directly correlated with AMPs level and the effect. ALT is a specific enzyme found bountifully in the cytosol of hepatocytes. A High level of ALT in serum is released to the hepatic cell problem (Huang et al., 2006). The results showed that no significant differences were observed in ALT ( $p>0.05)$ among all groups, except the $800 \mathrm{mg} / \mathrm{kg}$ group. This study indicated that the supplementation of AMPs in the diet for 68 days positively influenced on TP, TG and ALT in swamp eel serum.

\section{Serum Phosphatase Activity}

The results indicated that the serum phosphatase activity was significantly increased with the increase of AMPs concentration in the diet (Table 4).

Table 4. Effect of AMPs on serum phosphatase activity of swamp eels.

\begin{tabular}{ccc}
\hline AMPs & $\begin{array}{c}\text { Alkaline phosphatase (ALP) } \\
\text { (King unit/100ml) }\end{array}$ & $\begin{array}{c}\text { Acid phosphatase (ACP) } \\
\text { (unit/100ml) }\end{array}$ \\
\hline 0 & $4.98 \pm 0.56^{\mathrm{a}}$ & $4.72 \pm 0.61^{\mathrm{a}}$ \\
200 & $5.00 \pm 0.69^{\mathrm{a}}$ & $4.88 \pm 0.70^{\mathrm{a}}$ \\
400 & $5.56 \pm 0.76^{\mathrm{a}}$ & $6.11 \pm 0.92^{\mathrm{b}}$ \\
600 & $6.63 \pm 0.68^{\mathrm{b}}$ & $7.81 \pm 0.60^{\mathrm{b}}$ \\
800 & $6.94 \pm 1.32^{\mathrm{b}}$ & $7.13 \pm 1.56^{\mathrm{b}}$ \\
\hline
\end{tabular}

The data in the table is the mean \pm standard deviation $(n=6)$, the lower column of the same column data indicates that the difference is significant $(\mathrm{p}<0.05)$.

Alkaline phosphatase (ALP) activity possessed the highest activity when the AMPs concentration reached to 800 $\mathrm{mg} / \mathrm{kg}$ and the activity was significantly increased by $39.36 \%$ compared to the control. Eels feed with AMPs $600 \mathrm{mg} / \mathrm{kg}$ in the diet displayed excellent acid phosphatase (ACP) activity, which was significantly increased by $65.47 \%$ with reference to the control. However, the ACP activity was decreased in AMPs 800 $\mathrm{mg} / \mathrm{kg}$. We also evaluated the effect of different AMPs levels in diet on immunerelated enzymes. Immunity in aquatic is involved with two cooperative defense systems, including specific and nonspecific immunity. Phosphatase enzymes, including ALP and ACP, play a key role in animal non-specific immune (Dong et al., 2015).

ALP is a metal-containing enzyme found in the superficial parts and the striated border of epithelial cells in the fish foregut. ALP has a positive correlation with the absorption of glucose, lipid, calcium and phosphorus in the epithelial cells (Liu et al., 2010). ALP is sensitive to metal and its activity is considered as a 
stress marker to evaluate the effects of environmental toxicants, such as pollution of heavy metal.

Therefore, ALP is an essential enzyme for application and absorption in fish nutrition (Zhang et al., 2016). ACP is a marker enzyme for the plasma membrane that widely distributed in the lysosome, endoplasmic reticulum, and cytoplasm substrate outside the lysosome. ACP associates with many activities, including adjustment of metabolism, phosphate metabolism, energy transfer and signal transduction (Dong et al., 2015). Both ALP and ACP are associated with several metabolic processes, including molecular permeability, growth and cell differentiation and steroidogenesis (Mazorra et al., 2002). ACP has been used as a marker enzyme in lysosomal membranes and ALP is used as an apical membrane enzyme (Molina et al., 2005).

As shown in Table 4, the supplementation of AMPs at the dosage of 600 and $800 \mathrm{mg} / \mathrm{kg}$ significantly increased $(\mathrm{p}<0.05)$ serum ACP and ALP activities compared to the other groups. Serum ACP and ALP activities were increased after fed with AMPs. The serum content in ACP and ALP increased with all AMPs-treatments compared to that eels in control. But, the increase was significant $(\mathrm{p}<0.05)$ at AMPs 600 and $800 \mathrm{mg} / \mathrm{kg}$. AMPs were supported to increase the ALP activity in Litopenaeus vannamei (Chai et al., 2012), koi (Cyprinus carpio) (Lin et al., 2013) and ACP activity in swamp eels (Dong et al., 2015). These results suggest that AMPs have an influence on the immune-related enzyme activity in serum and increase the immune system in swamp eels.

\section{Serum Oxidase Activity}

AMPs (Table 5) had significantly affected serum SOD, GPx, and CAT $(\mathrm{p}<0.05)$. Three enzymes exposed the highest activity in AMPs $600 \mathrm{mg} / \mathrm{kg}$ in the diet. The SOD was significantly increased by $25.36 \%(\mathrm{p}<0.05)$ compared with the control. Besides, GPx was significantly developed by $22.10 \%(\mathrm{p}<0.05)$ and CAT significantly improved by $34.66 \%$ $(\mathrm{p}<0.05)$.

Table 5. $\quad$ Effect of AMPs on serum antioxidant enzyme activity of swamp eels.

\begin{tabular}{cccc}
\hline AMPs & $\begin{array}{c}\text { Superoxide dismutase } \\
(\mathrm{SOD})(\mathrm{U} / \mathrm{ml})\end{array}$ & $\begin{array}{c}\text { Glutathione peroxidase }(\mathrm{GPx}) \\
(\mathrm{U} / \mathrm{ml})\end{array}$ & $\begin{array}{c}\text { Catalase (CAT) } \\
(\mathrm{U} / \mathrm{ml})\end{array}$ \\
\hline 0 & $125.12 \pm 12.13^{\mathrm{a}}$ & $1129.56 \pm 53.27^{\mathrm{a}}$ & $1.76 \pm 0.12^{\mathrm{a}}$ \\
200 & $126.70 \pm 11.52^{\mathrm{a}}$ & $1140.11 \pm 60.39^{\mathrm{a}}$ & $1.81 \pm 0.09^{\mathrm{a}}$ \\
400 & $137.59 \pm 9.38^{\mathrm{b}}$ & $1256.31 \pm 59.62^{\mathrm{b}}$ & $2.15 \pm 0.22^{\mathrm{b}}$ \\
600 & $156.85 \pm 12.70^{\mathrm{c}}$ & $1379.23 \pm 107.66^{\mathrm{c}}$ & $2.37 \pm 0.08^{\mathrm{b}}$ \\
800 & $140.41 \pm 21.21^{\mathrm{b}}$ & $1208.81 \pm 155.02^{\mathrm{b}}$ & $2.16 \pm 0.45^{\mathrm{b}}$ \\
\hline
\end{tabular}

The data in the table is the mean \pm standard deviation $(n=6)$, the lower column of the same column data indicates that the difference is significant $(\mathrm{p}<0.05)$.

Fish possesses a unique immune system against pathogens. The immune parameters are related to their antioxidant abilities (Salinas and Magadán, 2017). Both enzymatic and non-enzymatic antioxidants are generated and detoxified free radicals in fish (Abhijith et al., 2016). Antioxidant enzymes, including superoxide dismutase (SOD), catalase (CAT), glutathione reductase (GR) and glutathione peroxidase (GPx) are directly supported cells to neutralize free radicals
(Yusof et al., 2017). SOD and CAT are involved in the protection of cells from the potentially toxic effects of environmental pollutants (Velkova-Jordanoska et al., 2008). SOD is an important antioxidase that scavenge oxy-radicals in the body (Ruiz-Gutiérrez et al., 2001). CAT is one of the major antioxidant enzymes present in all living tissues. CAT catalyzes $\mathrm{H}_{2} \mathrm{O}_{2}$ turn to oxygen and water in order to stop the action of hydroxyl radical in tissues. GPx is one of the major intracellular antioxidant 
enzymes that neutralize hydrogen peroxide to water and the responding stable alcohols (Yusof et al., 2017). These antioxidant enzymes counteract the active oxygen radicals to reduce the damaging effects of oxidants in the body.

Antioxidants have been used as a parameter to determine fish's health and immune system. They can be referred to as the ability of the fish body to eliminate excess oxygen radicals in normal conditions (Dong et al., 2015). The results showed that the activities of SOD, GPx and CAT increased with higher AMPs concentration. The SOD, GPx and CAT of AMPs-600 mg/kg exhibited higher than that of the control group, which was reflected on eels immune ability. The results showed that the supplementation with AMPs in diet enhanced the antioxidant ability in the eel body to detoxify free radicals and protect cells. These results were agreed with many pieces of research reported that AMPs encouraged antioxidant activity and enhanced the immunity of L. vannamei
(Chen et al., 2010), Carassius auratus gibelie (He et al., 2011), and tilapia (Jiang et al., 2011) serum.

\section{Survival Rate of Swamp Eels After Challenge with $A$. hydrophila}

Pathological changes present in the organs of dead fish mainly showed congestion, hemorrhage, extensive tissue degeneration, and necrosis of the liver and kidney. A. hydrophila is a free-living gramnegative pathogen bacterium that widespread in freshwater lakes and streams, domestic tap water, and sewage. It can cause hemorrhagic septicemia and Epizootic Ulcerative Syndrome (EUS) in fish farming over Asian countries (Yesmin et al., 2004). In this study, supplementation with AMPs in diet could increase the survival rate of swamp eels after challenge with $A$. hydrophila and the highest survival rate was found when the supplementation at $800 \mathrm{mg} / \mathrm{kg}$ in the diet (Table 6).

Table 6. Effect of AMPs on the survival rate of swamp eels after with A. hydrophila bacteria challenge.

\begin{tabular}{ccccc}
\hline AMPs & Fish (H) & Survival $(\mathrm{H})$ & Survival rate (\%) & $\begin{array}{c}\text { Immune protection } \\
(\%)\end{array}$ \\
\hline 0 & 40 & 7 & $17.50^{\mathrm{a}}$ & - \\
200 & 40 & 8 & $20.00^{\mathrm{ab}}$ & 14.28 \\
400 & 40 & 9 & $22.50^{\mathrm{b}}$ & 28.57 \\
600 & 40 & 12 & $30.00^{\mathrm{c}}$ & 71.43 \\
800 & 40 & 13 & $32.50^{\mathrm{c}}$ & 85.71 \\
\hline
\end{tabular}

Different lowercase letters in the same column of data indicate significant differences $(\mathrm{p}<0.05)$.

Compared to the control, the survival rate of AMPs $800 \mathrm{mg} / \mathrm{kg}$ was significantly increased by $15 \%$ and the immune protective capacity was $85.71 \%$ $(\mathrm{p}<0.05)$. Supplementation of AMPs corresponding to enhance fish's immune protection capacity on $A$. hydrophila and improve the survival rate in fish. A similar result was found in the research of Chen et al. (2010) who found that AMPs enhanced the survival rate of $L$. vannamei after challenged with Aeromonas veronii. It is concluded that AMPs supplementation enhances non-specific immunity and disease resistance and promotes the growth of swamp eels.

\section{CONCLUSION}

This study revealed that dietary supplementation with AMPs could improve the growth, survival rate, serum biochemical parameters (TP, TG, ALT), serum phosphatase activity (ALP, ACP), serum antioxidant activity (SOD, GPx, CAT), and survival rate after challenge with $A$. hydrophila in swamp eels. The recommended supplement level of AMPs in the diet for swamp eels is $600 \mathrm{mg} / \mathrm{kg}$. 
Further studies are required to study the activity of AMPs on fish performance.

\section{ACKNOWLEDGMENT}

The authors are thankful to College of animal sciences, Yangtze University for their support in fish samples and laboratory. We are grateful to Shenzhen Sunsmile Biotechnology Co., Ltd. for the AMPs samples and financial support to carry out this work.

\section{REFERENCES}

Abhijith, B.D., Ramesh, M. and Poopal, R.K., 2016. Responses of metabolic and antioxidant enzymatic activities in gill, liver and plasma of Catla catla during methyl parathion exposure. The Journal of Basic \& Applied Zoology, 77, pp. 31-40. https://doi.org/10.1016/j.jobaz.20 15.11 .002

Chai, X., Leng, X., Li, X., Shan, L. and Song, H., 2012. Effect of antibacterial peptide on growth and serum non-specific immunity of Litopenaeus vannamei. Freshwater Fisheries, 42(4), pp. 59-62. https://e n.cnki.com.cn/Article_en/CJFDTota 1-DSYY201204012.htm

Chen, B., Cao, J., Chen, P., Zhao, H., Lan, H. and Zhu, X., 2010. Effects of antibacterial peptides of Musca domestica on growth performance and immune-related indicators in Litopenaeus vannamei. Journal of Fishery Sciences of China, 17(2), pp.258-265. https://en.cnki.com.cn /Article_en/CJFDTotal-ZSCK20100 2011.htm

Chen, Y.B., Hu, J., Lyu, Q.J., Liu, L.J., Wen, L.F., Yang, X.K. and Zhao, H.H., 2016. The effects of natucin Cnatucin $\mathrm{P}$ mixture on blood biochemical parameters, antioxidant activity and non-specific immune responses in tilapia (Oreochromis niloticus). Fish \& Shellfish Immunology, 55, pp.367373. http://doi.org/10.1016/j.fsi.2 016.06 .016
Cruz, J., Ortiz, C., Guzmán, F., FernándezLafuente, R. and Torres, R., 2014. Antimicrobial peptides: promising compounds against pathogenic microorganisms. Current Medicinal Chemistry, 21(20), pp.2299-2321. http://doi.org/10.2174/092986732 1666140217110155

Daneshmand, A., Kermanshahi, H., Sekhavati, M.H., Javadmanesh, A. and Ahmadian, M. 2019. Antimicrobial peptide, cLF36, affects performance and intestinal morphology, microflora, junctional proteins, and immune cells in broilers challenged with E. coli. Scientific Reports, 9, pp.14176. http://doi.org/10.1038/s41598-01 9-50511-7

Dong, X., Zhang, D., Chen, Y., Wang, Q. and Yang, Y., 2015. Effects of antimicrobial peptides (AMPs) on blood biochemical parameters, antioxidase activity, and immune function in the common carp (Cyprinus carpio). Fish \& Shellfish Immunology, 47(1), pp.429-434. http://doi.org/10.1016/j.fsi.2015.0 9.030

He, Y., Chen, J., Liu, B., Zhou, Q., Zhou, C. and Xie, J., 2011. Effect of antibacterial peptides on the growth, factors associated with immunity and antioxidation, and intestinal microflora of allogynogenetic crucian carps. Journal of Liaoning University (Naural Science Ed.), 38(2), pp.149153. https://en.cnki.com.cn/Article _en/CJFDTotal-LNDZ201102013.ht m

Hu, F., Gao, X., She, R., Chen, J., Mao, J., Xiao, P. and Shi., R., 2017. Effects of antimicrobial peptides on growth performance and small intestinal function in broilers under chronic heat stress. Poultry Science, 96(4), pp.798-806. http://doi.org/10.338 2/ps/pew379

Huang, L., Mo, Y., Wu, Z., Rad, S., Song, X., Zeng, H., Bashir, S., Kang, B. and Chen, Z., 2020. Occurrence, 
distribution, and health risk assessment of quinolone antibiotics in water, sediment, and fish species of Qingshitan reservoir, South China. Scientific Reports, 10, 15777. https://doi.org/10.1038/s41598-02 0-72324-9

Huang, X., Choi, Y., Im, H., Yarimaga, O., Yoon, E. and Kim, H., 2006. Aspartate aminotransferase (AST/ GOT) and alanine aminotransferase (ALT/GPT) detection techniques. Sensors, 6(7), pp.756-782. https://d oi.org/10.3390/s6070756

Izadpanah, A. and Gallo, R.L., 2005. Antimicrobial peptides. Journal of the American Academy of Dermatology, 52(3), pp.381-390. http://doi.org/10.1016/j.jaad.2004 .08 .026

Jiang, S., Wang, B.L., Liu, M. and Jiang, K., 2011. Effects of recombinant antimicrobial peptides on growth and immunity in tilapia. Journal of Fishery Science of China, 18(6), pp.1308-1314.

Khanh, N.H. and Ngan, H.T.B., 2010. Current practices of rice field eel Monopterus albus (Zuiew, 1793) culture in Vietnam. Aquaculture Asia Magazine, XV(3), pp.26-29. http://li brary.enaca.org/AquacultureAsia/A rticles/oct-dec-2010/rice-field-eelvietnam.pdf

Lei, J., Sun, L., Huang, S., Zhu, C., Li, P., He, J., Mackey, V., Coy, D.H. and He, Q., 2019. The antimicrobial peptides and their potential clinical applications. American Journal of Translational Research, 11(7), pp.3919-3931. https://www.ncbi.nl m.nih.gov/pmc/articles/PMC66848 87/

Lin, X., Mao, S., Yang, Y., Lin, S. and Luo, L., 2013. Effects of antimicrobial peptides supplementation on growth, non-specific immunity and disease resistance of koi (Cyprinus carpio koi). Chinese Journal of Animal Nutrition 25(8), pp. 18601865.
Liu, W., Zhang, X. and Wang, L. 2010. Digestive enzyme and alkaline phosphatase activities during the early stages of Silurus soldatovi development. Zoological Research, 31(6), pp.627-632. https://hdl.han dle.net/1807/64612

Matsumoto, S., Kon, T., Yamaguchi, M., Takeshima, H., Yamazaki, Y., Mukai, T., Kuriiwa, K., Kohda, M. and Nishida, M., 2010. Cryptic diversification of the swamp eel Monopterus albus in East and Southeast Asia, with special reference to the Ryukyuan populations. Ichthyological Research 57, pp.71-77. http://doi.org/10.100 7/s10228-009-0125-y

Mazorra, M.T., Rubio, J.A. and Blasco, J., 2002. Acid and alkaline phosphatase activities in the clam Scrobicularia plana: kinetic characteristic and effects of heavy metals. Comperative Biochemistry and Physiology Part B: Biochemistry and Molecular Biology, 131(2), pp.241-249. https://doi.org /10.1016/S1096-4959(01)00502-4

Miah, M.F., Anwar, S., Ali, M.H., Naser, M.N. and Ahmed, K., 2018. Assessment of genetic diversity of freshwater mud eel (Monopterus cuchia) using RAPD and RFLP markers. Journal of Aquaculture Research \& Development, 9(7), pp.18. http://doi.org/10.4172/21559546.1000543

Miah, M.F., Naser, M.N. and Ahmed, M.K., 2015. The freshwater mud eel, Monopterus cuchia-a review. Journal of Global Biosciences, 4(3), pp.17801794. https://www.mutagens.co.in /jgb/vol.04/3/19.pdf

Molina, R., Moreno, I., Pichardo, S., Jos, A., Moyano, R., Monterde, J.G. and Cameán, A., 2005. Acid and alkaline phosphatase activities and pathological changes induced in tilapia fish (Oreochromis sp.) exposed subchronically to microcystins from toxic cyanobaterial blooms under laboratory conditions. Toxicon, 
46(7), pp.725-735. https://doi.org/ 10.1016/j.toxicon.2005.07.012

Pasupuleti, M., Schmidtchen, A. and Malmsten, M., 2011. Antimicrobial peptides: key components of the innate immune system. Critical Reviews in Biotechnology, 32(2), pp.143-171. http://doi.org/10.310 9/07388551.2011.594423.

Ramatla, T., Ngoma, L., Adetunji, M. and Mwanza, M., 2017. Evaluation of antibiotic residues in raw meat using different analytical methods. Antibiotics, 6(34), pp.1-17. http://d oi.org/10.3390/antibiotics6040034

Ruiz-Gutiérrez, V., Vázquez, C.M. and Santa-Maria, C., 2001. Liver lipid composition and antioxidant enzyme activities of spontaneously hypertensive rats after ingestion of dietary fats (fish, olive and higholeic sunflower oils). Bioscience Reports, 21(3), pp.271-285. http://d oi.org/10.1023/A:1013277914213

Salinas, I. and Magadán, S., 2017. Omics in fish mucosal immunity. Developmental \& Comparative Immunology, 75, pp. 99-108. http:// doi.org/10.1016/j.dci.2017.02.010

Su, Y., Chen, G., Chen, L., Li, J., Wang, G., He, J., Zhan, T., Li, Y., Yan, M., Huang, Y., Qin, Q., Dan, X. and Sun, H., 2019. Effects of antimicrobial peptides on serum biochemical parameters, antioxidant activity and non-specific immune responses in Epinephelus coiodes. Fish \& Shellfish Immunology, 86, pp.1081-1087. http://doi.org/10.1016/j.fsi.2018.1 2.056

Velkova-Jordanoska, L., Kostoski, G. and Jordanoska, B., 2008. Antioxidative enzymes in fish as biochemical indicators of quality pollution. Bulgarian Journal of Agricultural Science, 14(2), pp.235-237. http:// agrojournal.org/14/02-20-08.pdf

Wang, S., Zeng, X., Yang, Q. and Qiao, S., 2016. Antimicrobial peptides as potential alternatives to antibiotics in food animal industry. International Journal of Molecular
Science, 17(603), pp. 1-12. http://d oi.org/10.3390/ijms17050603.

Xiao, H., Shao, F., Wu, M., Ren, W., Xiong, X., Tan, B. and Yin, Y., 2015. The application of antimicrobial peptides as growth and health promoters for swine. Journal of Animal Science and Biotechnology, 6, pp.19. http://doi.o rg/10.1186/s40104-015-0018-z

Yang, Z., Wang, Z.Y., Yang, H.M., Xu, L. and Gong, D.Q., 2017. Effect of dietary methionine and betaine on slaughter performance, biochemical and enzymatic parameters in goose liver and hepatic composition. Animal Feed Science and Technology, 228, pp.48-58. http://doi.org/10.10 16/j.anifeedsci.2017.04.003

Yesmin, S., Rahman, M.H., Hussain, M.A., Khan, A.R., Pervin, F. and Hossain, M.A., 2004. Aeromonas hydrophila infection in fish of swamps in Bangladesh. Pakistan Journal of Biological Sciences, 7(3), pp.409411.

Yusof, W.R.W., Ahmad, F.B. and Swamy, M., 2017. A brief review on the antioxidants and antimicrobial peptides revealed in mud crabs from the genus of Scylla. Hindawi Journal of Marine Biology, 2017, pp.1850928. http://doi.org/10.115 5/2017/1850928

Zhang, A., Chen, X., Zhang, R., Zhang, W., Jin, C. and Li, C., 2016. Identification of relevant biomarkers in mercury exposed clam Venerupis philippinarum. The Israeli Journal of Aquaculture, 68, pp.1-10. http://h dl.handle.net/10524/54959

Zhou, X., Wang, Y. and Li, W., 2008. Effect of feeding apidaecin on common carp (Cyprinus carpio) growth performances and immune function. Aquaculture, 279(1-4), pp.108-112. http://doi.org/10.1016/j.aquacultu re.2008.04.024 